\title{
Bridging the Gap: Lottery-based Procedures in Early Parliamentarization *
}

\author{
Alexandra Cirone ${ }^{\dagger}$ \\ Brenda Van Coppenolle $\ddagger$
}

\begin{abstract}
Lottery-based rules were used in committee systems in $19^{\text {th }}$ century Europe, a key period of parliamentarization. We argue that both the adoption and benefits of lottery-based procedures were to prevent capture of early institutions by party factions, or groups of self-interested political elites. We analyze the effects of a political lottery in budget committee selection in the French Third Republic, using a micro-level dataset of French deputies from 1877 to 1914. Partial randomization resulted in the appointment of young, skilled, middle class deputies at the expense of influential elites. Once parties gained control of committee assignments in 1910, however, they once again favored elites and loyal party members in selection. We link this practice to party development by showing that cohesive parties were behind the institutional reform that ultimately dismantled this selection process. We also show that this was the case in the contexts of Imperial Germany (1871), Denmark (1848), Netherlands (1815), Austria (1875) and France (1870). Across Europe, lottery-based procedures thus played a 'sanitizing' role during the transformation of emerging parliamentary groups to unified, cohesive political parties.
\end{abstract}

\footnotetext{
*We thank Ahmel Ahmed for inspiration, and the workshop participants in Bremen 2016.

${ }^{\dagger}$ Email: a.e.cirone@lse.ac.uk, Fellow, Department of Government, London School of Economics and Political Science, Houghton Street, London WC2A 2AE, UK.; Graduate Student, Columbia University

${ }^{\ddagger}$ Email: b.k.s.van.coppenolle@fsw. leidenuniv.nl, Assistant Professor, Leiden University, Institute of Political Science, Wassenaarseweg 52, 2333 AK Leiden, The Netherlands.
} 


\section{INTRODUCTION}

Political lotteries have a long history in the democratic tradition. In ancient Athens, over 7,000 government officials were chosen by lot, in a practice called sortition, including the governing assembly called the Council of 500 (Colomer, 2014). Ancient Rome also practiced variations of sortition, and so did Italian city-states, notably Florence and Venice, from the medieval to the Renaissance periods (Tridimas, 2002). Both Spain and England used such procedures for magistrates and municipal councils in the 15th and 16th centuries (Engelstad, 1989), and regions in Switzerland appointed the office of mayor by lot as late as 1837 (Elster, 1989). Sortition affects political selection, behavior, and outcomes: studies have shown lotteries in the earliest democracy in Athens ensured equal opportunity for individuals from all socio-economic groups (Taylor, 2007), and in the medieval Florentine Republic leader selection by lottery ensured rotation among competing business elites (Abramson, 2016).

The selection of entire governing bodies by sortition, however, is no longer a common feature of contemporary democratic institutions.1 Instead, random selection has been incorporated into parts of the selection of political office. We define such a practice as a lottery-based procedure: a selection process that incorporates an element of randomization, but falls short of pure sortition.

There are a number of examples in the context of legislative assemblies. Committee seniority rankings and assignment orders are partially determined by lottery in the US Congress (Kellerman and Shepsle, 2009) and the German Bundestag (Buchstein and Hein, 2009), respectively. Ties in the election of presiding officers use lotteries in eight European countries (Rasch, 1995), and both the British and Indian parliaments randomly select the set of questions to the prime minister (Wallack, 2008). Victorian Britain employed a lottery to choose judges for electoral corruption trials (Eggers and Spirling, 2014), and lotteries decide which private member bills will be considered in Britain (Bowler, 2010), Canada (Loewen et al, 2014), and New Zealand (Williams and Indridason, 2014). The introduction of lotteries is becoming increasingly salient in the dialogue on political reform. Buchstein and Hein (2009) argue for introducing a lottery element in the appointment processes of the European Union.Van Reybrouck (2016) provides an extensive case to reintroduce sorition to elected

\footnotetext{
${ }^{1}$ The American jury system is an exception.
} 
bodies, and selecting the second chamber by sortition has been suggested for the UK House of Lords (Barnet and Carty, 2009), and the French Assembly (in Ségolène Royal's 2007 presidential platform).

Here we focus exclusively on lottery-based procedures in the selection of parliamentary or constitutional committees ${ }^{2}$ Yet there are few studies that empirically analyze the effects of lottery-based procedures on the types of politicians selected and their subsequent policy choices. Studies of the randomization of seniority or committee exile in the US Congress (Broockman and Butler 2012; Kellerman and Shepsle 2009; Grimmer and Powell 2013) or of committee appointment in 19th century France (Authors, 2016) focus on the benefits to committee service, but not on the incentives that this type of political selection gives to emerging parties for changing the rules. Are there strategic reasons to introduce lotterybased procedures, and what consequences can we expect for political selection and behavior in parliamentary committees?

This paper considers the use of lottery-based rules in newly formed legislative institutions in $19^{\text {th }}$ century Europe, during the process of parliamentarization. We hypothesize that the initial adoption of lottery-based procedures was to prevent capture of early institutions by factions, or groups of self-interested political elites. These procedures were able to play such a role for two reasons. First, lottery-based rules decrease the potentially harmful influence of political factions by adding unpredictability to the selection process, reducing the ability of a particular group to subvert the committee for its own ends. Second, lottery-based rules help ensure more equal access to political office; either by giving a larger set of politicians the opportunity to compete directly for holding office or the ability to influence the appointment of those who do.

We set out our hypotheses of lottery-based procedures for political selection and behavior in a framework in which weak or strong parties hold different preferences. By design, lotterybased procedures emphasize individual skills or expertise over group affiliation, and reduce the influence of organized groups. It is clear that organized parties would favor institutional procedures that give advantages to groups, namely election or appointment; but in the

\footnotetext{
${ }^{2}$ While outside the scope of this paper, outside the legislative arena, randomly assigned focus groups (in the UK, see Goodin, 2008) or deliberative polling (Fishkin 2011) have shown that such groups are equally capable of analyzing public policy as elites.
} 
context of weak parties, early institution builders purposefully used lottery-based procedures at least partly in order to protect their new institutions from potentially pernicious elites. As parties become stable, and threat of factions disappear, then the costs of lottery-based procedures outweigh the benefits. It follows that organizational strength of parties drives the choice to implement lottery-based procedures; the adoption then dissolution of lottery-based procedures can be explained by changes in the parliamentarization of the parties. As parties become stable, and threat of factions disappear, then the costs of lottery-based procedures outweigh the benefits.

To further test our hypotheses, we turn to one case in more detail. We discuss the adoption of a lottery-based procedure to select members for the powerful budget committee in the French Third Republic, using a micro-level dataset of French deputies from 1877 to 1914. The budget committee was a yearly, standing committee formed of 33 members tasked with reviewing and proposing amendments to the government's budget proposals. This committee was the only standing committee that was consistently appointed since the start of the republic in 1870. For the first three decades of the republic, a lottery-based procedure to select budget committee members was in place. Each year, the French legislature was divided into 11 randomly assigned bureaux; each bureau met briefly to appoint 3 members to the powerful budget committee and was then dissolved.

We find that while this procedure was in place, younger, centrist, and middle class deputies were consistently more likely to be selected at the expense of wealthy elites. $I^{3}$ The dismantling of the bureaux system in 1910 also shows the relationship between parliamentarization and party development; we show that parties that had become cohesive were more likely to support the reform bill that gave partisan control over committee selection. Further, once parties gained control over committee appointments, not only is there evidence they once again favored elites in the selection process, but that they used their powers to select loyal party members.

We then find further support for our arguments about the adoption, consequences, and

\footnotetext{
${ }^{3}$ While such individual factors systematically favored appointment, the consequences of the random element in the composition of the bureaus introduced by the lottery were not trivial. Authors (2016) find that particularly those deputies lucky to be at the winning end of the randomisation were more likely to be appointed to the budget committee. These lucky deputies would also become more likely to later submit budget-related legislative amendments and to be promoted to a ministerial position.
} 
discontinuation of lottery-based procedures from a number of 19th century parliamentary arenas, including Imperial Germany (1871), Denmark (1848), the Netherlands (1815), and Austria (1875). All countries incorporated lottery-based procedures in committee systems in the early stages of parliamentary development, in the context of weak party systems consisting of loosely organized 'proto-parties.' The primary rationale for their adoption is strikingly similar across a variety of contexts: they were used among widespread distrust for new political factions, and in order to ensure more egalitarian distribution of key posts. These procedures were typically dismantled or subverted once parties were organized enough to control legislative activity. Lottery-based procedures thus played a gatekeeping role during the transformation of emerging parliamentary groups to unified, cohesive political parties.

This paper proceeds as follows. First, we discuss our theoretical expectations for how lottery-based procedures within committee structures affect political selection. Based on these expectations, we can hypothesize why young parliaments would want to adopt such procedures and why more institutionalized parties would later want to abolish them again. In Section 3 we review the case of France in detail, which we will use to conduct a test of our theoretical claims. In Section 4, we outline our data and research design, and then provide evidence consistent with our hypotheses for political selection. More cohesive parties eventually vote to abolish lotteries, and are more likely to appoint loyal members after they gain control over committee appointments. The next section, Section 5, lends further support to our arguments by providing several other examples of lottery-based procedures in 19th century parliamentary systems. Our paper concludes by discussing the contribution of our research to the literature on legislative institutions in new democracies.

\section{Rationale for Lottery-Based Procedures}

Democratic theory has long argued the benefits of selection by lot. Thinkers like Aristotle, Montesquieu and Rousseau considered sortition to be the only truly democratic process, and all other forms of selection to be of an aristocratic nature (Engelstad, 1989). Political lotteries are often motivated in political theory by criteria of fairness: they might improve representation of diverse groups and more evenly distribute the benefits and training of political office. Lottery-based procedures, however, share characteristics of both lotteries and 
human selection. Thus even partial lotteries could enhance the legitimacy of the new system among diverse groups, particularly if lottery-based selection is combined with regular rotation of those holding the office. But how do such procedures differ in expectation compared to other forms of selection? What explains why actors would agree to partial lotteries? Who benefits from the lottery-based procedures, and who can be expected to favor a change to elections or appointments?

\subsection{Sortition, lottery-based procedures, elections and appoint- ments}

In order to study the use of lottery-based procedures in committee selection, we must first distinguish this procedure from other selection methods used to allocate higher office. Here, we discuss four types of committee selection, ranging from pure random selection to appointment: sortition, lottery-based procedures, election within parliament, and appointment by parties. Each selection procedure has different implications for both the probability of an individual obtaining a committee post, and the resulting composition of that committee. We focus on how the various options influence the probability of selection, the committee composition, incentives for the individual legislator, and incentives for political parties.

Sortition. While pure sortition of legislative committees is rare, it serves as an important conceptual counterfactual. Above all, lotteries ensure equal selection probabilities. The completely random allocation of committee positions ensures that each legislator has the same chance of being chosen. Over multiple draws, lotteries also result in a committee that is more or less representative of the chamber on average; however, individual draws can be biased due to pure chance. In this, lotteries are susceptible to concerns about legitimacy; when faced with an unpleasant draw and corresponding extreme outcomes, citizens could be quick to doubt the honesty of the process of drawing lots (Elster, 1989).In terms of incentives, lotteries introduce uncertainty - neither individuals nor parties have influence over the selection process. For a politician, random selection potentially eliminates those most qualified or interested in political office and removes the incentive to invest in either 
skill acquisition or party membership $4^{4}$ For a political party, randomization undermines a group's influence in the committee (since its strength depends on the draw), and committee assignments cannot be used as sticks or carrots to incentivize party loyalty. On the positive side, randomisation shelters politicians from influences of corruption or special interests before selection. It can also reduce the ex ante one-sided influence of powerful groups, and ensure more equal representation of minority interests.

Elections and Appointments. If lotteries and lottery-based procedures are mechanical in that they remove the human element, on the other side of the spectrum are elections and appointments. While two separate procedures, the selection of committees by parliamentary election and the appointment of committees by parties are similar in political selection that is driven by the preferences of organized - and often majority - groups. Selection probabilities are biased and unequal, and entirely a function of the groups that control a majority in the chamber, either because the individual is elected with the support of the party in the chamber, or directly chosen by party. Committee composition will also reflect the preferences of such groups. For an individual politician trying to negotiate a spot on a committee, there are high incentives to invest in party membership and loyalty, as well as skill. For a party, the use of these procedures transform committee assignments into powerful selective incentives that can be used to reward or punish member behavior.

Lottery-based procedures. If sortition removes the human element from the selection process, a lottery-based procedure simply restricts it. Generally, the unrestricted pursuit of political office is typically dominated by the wealthy and well-resourced elites. Lotteries help ensure more equal access to political office (Manin, 1997; Stone 2009; Lopez Guerra 2010), and in this, the procedure is distinctly non-partisan (Sutherland, 2004). Lotterybased procedures combine these features with those of partisan election, and differ from the other types in that they are typically a two stage process - the chamber is randomly assigned into groups in the first stage, and then those groups select the committee members in the second. The first stage mirrors the expectations found in lotteries - equal selection probabilities, and uncertainty as a result of randomizing that makes it much more difficult

\footnotetext{
${ }^{4}$ This is why even in democratic Athens the important executive functions of the generals who decided on military interventions and strategy, were not assigned by lot. Artistotle was reportedly against sortition for magistrates, which required at least some skill (Tridimas, 2012).
} 
for a specific group to stack the deck in order to advance its interests within a deliberative body. This undermines elite coordination and influence.

Yet the second stage, where committee members are selected, involves a human choice element. This affects behavior in a different way. Negotiating for a committee position, even within a small randomly selected group, would require the acquisition of skill or expertise (as in election or appointment). Party affiliation could also matter, depending on the draw; yet lottery-based procedures still greatly reduce the ability of parties to significantly affect assignments. Thus lottery-based procedures combine institutional elements to incorporate more equal selection probabilities, emphasize investment individual skills or expertise over group affiliation, and reduce the influence of specific parliamentary groups in the selection process.

\subsection{Adoption of lottery-based procedures}

We highlighted the advantages and disadvantages of choosing various methods of selection, and how lottery-based procedures fit into the potential set of options. Preferences of emerging parties over lottery-based procedures are a function of accurate expectations of outcomes resulting from such rules. Lottery-based procedures should emphasize individual skills or expertise over group affiliation, and reduce the influence of organized groups. When can we expect parties to prefer such procedures? And how do the adoption and dissolution of such legislative procedures relate to partisan development?

We argue that the structure of the party system, particularly the organization of the parties themselves, influenced the adoption of lottery-based procedures. We take as our starting point a standard definition of political party, namely a political group, defined by a label and stable membership, whose members act in concert to achieve goals of political office, election, or policy (Sartori 1976, Aldrich 1995, Schumpeter 1962). In this study we focus on democratizing parliaments, and therefore our actors of interest are emerging protoparties. In 19th century Europe, party organizations typical began as internally created groups within parliament (Duverger, 1954). It is true some groups were more externally based than others (i.e. the small but rising Socialist currents), most began as elite- based 'cadre' parties, and were so in the context of our study. 
Drawing from the literature on party institutionalization, we identify criteria by which to assess the weakness of early parliamentary groups: i) stability in membership and party label, ii) formal party organization, and iii) stable intraparty competition (Mainwairing and Scully, 1995; Levitsky, and Cameron, 2003; Lupu and Riedl, 2013). First, strong parties have a meaningful party label and defined membership, and the party as an organization must be be valuable in and of itself (that is, the group must exist outside a set of personalistic leaders). Second, the party should exhibit organizational stability, in the routinization of rules, procedures, end expectations governing the group 5 Third, parties must exist across electoral cycles, in a way that demonstrates at least some continuity among party alternatives.

Thus parties that have stability in membership, continuity, and internal organization we term organized, or 'strong'. Most importantly, it means that these party groups could viably contest and compete for power under appointment-based procedures. For these reasons, it is clear that organized parties would favor institutional procedures that give advantages to groups, namely election or appointment. Both procedures anchor the probability of selection to group membership, and increase the probability that the committee will consist of members from and reflect the preferences of the organized groups. In addition, parties can use committee assignments as selective incentives to further induce loyalty by rewarding loyalists or punishing defectors. Given this, strong parties would want appointment or election.

Weakly organized parties, however, prefer institutional procedures that reduce the influence of specific groups and ensure more egalitarian selection. Weak party systems, while common in a new democracy, are often characterized by multiple groups with fluid membership, shifting or personalistic leadership, and the reinvention of the group from one term to the next. This increases uncertainty, and makes bargaining over committee seats and policy more unpredictable. As a result, when choosing committee selection procedures, the chamber may not want to delegate selection power or influence over committee composition exclusively to weak or unknown groups.

In this paper we argue that the initial adoption of lottery-based procedures to appoint committees across 19th century Europe occurred in a context in which institution builders

\footnotetext{
${ }^{5}$ One could also include electoral stability in this condition, defined as consistent support and regularized expectations or norms from voters. Since the parties that form the basis of our study are primarily not based in the electorate during this period of time, we do not discuss this dimension here.
} 
wanted to prevent capture of early legislative institutions by factions, or groups of selfinterested political elites. Particularly when parties are weak, the process of establishing parliamentary or constitutional committees is susceptible to elite capture, and early institutional configurations can have path dependent effects on long term development of the parliament. This was the case in the United States, France, and Great Britain, where early political parties were viewed as elite-driven factions that existed as a threat to democracy, and maintaining the stability of new republican institutions was a real concern (Colomer, 2014).

Lottery-based procedures are an effective way to guard against elite capture, because lottery-based procedures play a "sanitizing role" (Stone 2009), by protecting the selection process from those who would "subvert the process for their own ends" (Dowlen 2009). Scholars have argued this anti-factional, anti-partisan role was the rationale behind the adoption of sortition for the governing committees in the early republics of Athens, Florence, and Venice; such procedures reduced the ability of one party or family to develop a permanent power base (Dowlen 2009; Engelstad 1989). Under this selection rule, while the committee composition may be uncertain because of biases in the selection process, it will not be dominated by one particular group.

We know that politicians embrace institutional reform or change rules when it is in their interest (Capoccia and Ziblatt 2010), and historically, we often see legislative institutional procedures evolve to coordinate political activities when parties are weak (Krehbiel 1993; Dogan, 1979). In our cases, early institution builders purposefully used lottery-based procedures to protect their new institutions from potentially pernicious elites. In our case, in such an uncertain context with weak parties, the chamber may be more willing to put formal procedures in place that ensure equal access to political office and reduce the potential for partisan bargaining in selection in the face of a shifting party system. ${ }^{6}$ Randomisation is also a decision rule that constitution writers can unanimously agree to, a characteristic that is unlikely to hold for decision by majority rule (Buchannan and Tullock, 1969). Lotterybased rules were known to the institutional designers of the 19th century, and lottery-based

\footnotetext{
${ }^{6}$ This is similar to logic to work that looks at using legislation to constrain bureaucratic autonomy. Huber and Shipan (2002) argue that in when anticipated policy conflict is high, legislators use more detailed statues to instruct bureaucrats.
} 
rules offered the clear benefits of improving access to political office while still retaining an element of selection.

In the absence of strong parties, lottery-based procedures played an important role in regulating legislative committees. If the rationale for lottery-based parliamentary procedures was to protect the institution from weak or self-interested factions, then it follows that their removal is related to party development. In the context of weakly organized parties and high uncertainty, lottery-based procedures have clear advantages over election or appointment. However, as these conditions change as the party system develops, we should see a change in preferences. As parties become stable, and the threat of factions disappear, then the costs of lottery-based procedures outweigh the benefits. Parties want selection to depend on their membership, and want control over assignments to use as selective incentives. Thus it follows that organizational strength of parties drives the choice to implement lottery-based procedures; the adoption then dissolution of lottery-based procedures can be explained by changes in the parliamentarization of the parties.

The next section builds on this, and analyzes the effect of lottery-based procedures on elite selection and party development, using micro-level data from the Third Republic. To our knowledge, our paper is the first to explore how lottery-based procedures might govern early institutions until parties can consolidate.

\section{The Case of France}

Were the early constitution builders correct in their assumption that lottery-based procedures can undermine elite advantage? More specifically, how did lottery-based rules affect access to political office? We can use micro-level data in the French case to answer these questions. Our goal is to uncover to what extent the lottery-based procedure undermined elite advantage and gave entree to the new political class, and how this affected early partisan politics. Further, we examine the removal of lottery based procedures, and how this relates to partisan development. As we will show in France, the dismantling of the procedure coincides with the consolidation of parliamentary groups into organized parties, in this case the first official documentation of party membership in lists in 1910.

The French Third Republic incorporated a lottery-based procedure in committee ap- 
pointments, for the powerful budget committee in the Chamber of Deputies. The regime began in 1871, and during this time the parliament of the Third Republic was active and influential. The budget committee was an annual standing body with extensive control over the government's budget that rivaled even the cabinet for influence.7 It was also the only standing committee for much of the regime. To select the 33 members of the annual budget committee, France incorporated an element of randomization in the first part of the selection process. The approximately 580 members of the chamber were divided into 11 randomly assigned bureaux. Then each bureau met and within hours, selected 3 members to serve on the budget committee.

The practice of division into groups using a randomized system of bureaux was established a century prior to this, during the French Revolution. Bureaux were first utilized in the National Constituent Assembly, a body formed during the French Revolution by the Third Estate with the purpose of governing and drafting a constitution for the revolutionary regime (Mill, 1848). Bureaux drawn by lot reviewed proposals and elected committees responsible for drafting the text of the constitution. They were subsequently incorporated in the organization of the first Legislative Assembly in 1791, where they gained the power to elect the President and secretaries of the assembly as well as committee members (Frederiksen, 1936).

Historical evidence shows the lottery-based procedure was introduced for two reasons. First, the Constituent Assembly consisted of over 1200 members; by dividing the groups into bureaux, this could both induce a form of organization and a more efficient division of labor. This is the identical rationale for the creation of modern day committees. But, even more importantly, the creation of the bureaux procedure directly related to power struggles in the new republic. Randomly selecting deputies on a frequent basis would prevent the formation of 'cliques' and partisan behavior (Frederiksen, 1936), and counteract 'local and provincial loyalties' (Dawson, 1972). For the next century, the system of bureaux and the idea of legislative organization via commissions would be used in the various republics and empires prior to 1870 (Bodley 1898). When the Third Republic was established, the bureaux system was incorporated into the legislative rules of procedure governing the budget committee.

As we will demonstrate, the bureaux system was strategically retained for over 30 years

\footnotetext{
${ }^{7}$ The budget committee was a more stable institution; cabinets fell on average every 8 months, while the budget committee was consistently appointed yearly throughout the entire regime.
} 
to protect the unlimited individual initiative of deputies from partisan demands, and more broadly to prevent capture of the committee by various political cartels (Gooch, 1928; Usher, 1906). That is because for most of this era, parties were "cadre parties" (Duverger, 1954), consisting of loose parliamentary factions of high profile elites. Early parties existed only in the parliamentary arena, and on the ideological spectrum, the chamber was dominated by monarchists and conservatives on the far right, a rising contingent of socialists and radicalsocialists on the left, with a heterogeneous set of Radical parties in the center-right. Returning to our definition of party weakness, while French parties exhibited some degree of internal organization 8 they were lacking stability in membership and continuity, and there was instability in intraparty competition and membership. Party alternatives dissolved and reassembled each term, and membership was fluid. Multiple affiliations were common until the turn of the century; for example, as late as 1898 as much as $30 \%$ percent of the deputies held membership in two separate parliamentary parties. Particularly in the early years of the regime, French institution builders were concerned not only about weak parties, but the influence of aristocratic or anti-republican factions at the expense of minority groups.

The rationale for the use of the bureaux system is best presented by the deputies themselves, during the parliamentary debates that discussed standing committees in the 1880s, 1902, and finally 1910. Here, it is clear that deputies were worried about the fledgling party system. Advocates of the bureaux invoked two important arguments for the preservation of the lottery-based procedure. First, that there existed some factions that were hostile to the Republic, and the idea of democratic institutions. ${ }^{9}$

Second, deputies defended the system of bureaux by arguing that not only should deputies retain the non-partisan freedom to represent local constituents as they saw fit, but that parties were not yet unified enough to control committee assignments. As Lemire argued, "If I speak to you, socialists, it is because you are the only ones who are unified. But when I address others, the Radical Socialists, for example, I do not know where the party starts!"10 Historians outside of France also agree that the bureaux system served to check partisan activity (Bodley, 1898; Gooch, 1928). Woodrow Wilson (1911), in one of his seminal texts,

\footnotetext{
${ }^{8}$ Each parliamentary group was governed nominally by a committee, but these played no extraparliamentary or electoral function.

${ }^{9}$ Marcus Sibille, July 1, 1910, Journal Officiel.

${ }^{10}$ Lemire, July 1, 1910, Journal Officiel.
} 
addresses the French system:

"It will be seen that this arrangement, making the composition of the Bureaux dependent upon lot, as it does, and providing for the monthly reconstitution alike of the bureaux and of the committees which they select, must effectually prevent the recognition or maintenance of party lines in the formation either of the Bureaux or of the committees, and seems in that way very well adapted to check the factional ardors of the chamber."

On the other side of the debate, proponents of partisan control complained about perverse outcomes, in that the system could allocate politicians with the same skill set into one bureaux and only three could advance. They also sought guaranteed representation for minorities, arguing this would benefit the chamber; as the Socialist leader Jaurès stated "Gentlemen, let me tell you that the fair representation of all parties in all major committees is not only the guarantee of minorities, it is the guarantee of the majorities." 11 This viewpoint finally prevailed in 1910, when the lottery-based procedure was dissolved and the committee system was successfully reformed to give parliamentary groups control over committee assignments. Instead of election via the bureaux, committee positions were allocated proportionally to political parties, who then filled these slots using party-controlled lists.

Why in 1910? This coincides with membership stability and group continuity. Parliamentary groups were more clearly defined, and had consistently appeared the two terms prior. Deputies had stopped holding multiple affiliations, and the widespread use of official party labels in the electorate began with the 1906 term (Cole and Campbell, 1989; Hanley, 2006). Political associations had been made legal in 1901. The transition from weak to organized parties is made most evident by the first ever formal registration of party membership lists, as a result of the reform in 1910. Considering that for most of the 19th century in France, "the game of political labels became so subtle that it has no counterpart in other Western democracies" (Dogan, 1979, page 13) the fact that affiliations were published in the publicly available Journal Official is evidence of a clear transition from weak to organized parties. Once parties had consolidated into more unified actors, they removed the lottery-based procedure.

\footnotetext{
${ }^{11}$ Jean Jaurès, July 1, 1910, Journal Officiel
} 


\subsection{Data}

Here we analyze how the bureaux system affected the type of politicians who made it into office, and we choose to focus on elites. To do so, we rely on a micro-level dataset of deputies in the Chamber of Deputies, from 1881 to 1914. We collected information on yearly committee appointments, bureaux lists, and legislative activity and matched this to districtlevel electoral outcomes for the entire period. We also collected biographical information on deputy qualifications and careers.

We base our analysis of deputy selection on the categorization that mattered most to the new French Republic: the division between the landholding elite and the bourgeoise, or the rising middle class. In the $19^{\text {th }}$ century, the major bases of society were the elites, middle classes, peasants and workers (Price, 1987), though only the first two could realistically serve as a deputy in the chamber. But by the Third Republic, aristocratic influence had markedly declined in parliament. On the other side of the spectrum, until 1900 less than a third of of deputies came from the lower ranks of the bourgeoisie (Mayeur, 1975; Dogan, 1979). Instead, the new elites were the wealthy, influential land or capital owners, and the rising professional occupations of the grand bourgeoisie (liberal professions such as lawyers, doctors, professors, or bankers), and they played a dominant role in politics.

We identify a number of deputy characteristics that would indicate a member of the elite political class, and contrast these with members of the rising middle class. Here we rely on occupational data, taken from the district-level electoral results that provided the qualifications of candidates. We first create a variable to measure the elite, or the landed classes. This is an indicator variable, ELITE, and includes landowners, landlords, and owners of capital (such as factories) 12 As Table 1 demonstrates, this group tended to be older, from less competitive and smaller districts, and associated with the right or progressives. Importantly for our analysis, these elites had the wealth and influence to dominate early institutions.

Similarly, we create a variable to measure the upper middle class, called BourGEOIS or those deputies with professional occupations that were not landholders. This included

\footnotetext{
${ }^{12}$ We exclude those with small holdings, such as farmers, and industrial occupations, or non-owners; these are not part of the elite class.
} 
lawyers, bankers, doctors, professions, journalists, and similar liberal occupations (McPhee, 2004). These deputies were younger, with professional degrees, from more competitive districts, and more likely to support Radical and pro-republican ideals. Outside these two categories, the rest of the deputies in OTHER ClASSES are more heterogeneous and have less clear predictions; these include middle class but lower ranking professions such as clerks, engineers; or alternative professions such as priest or military. Still, this category is useful because by construction it is missing wealth and influence, and thus provides a comparison group.

Further, we are interested in the extent to which the lottery-based procedure affected the representation of various parliamentary factions. In the French case, deputies could hold multiple affiliations for most of the period in question, and party membership was not defined as in the modern sense. Using information on individual party faction affiliation, from both published lists and newspapers of the time, we code individuals as belonging to one of five main political and ideological blocs throughout this period. These were the conservatives, progressives, radicals, radical-soclialists, and socialists. Each bloc would typically be formed from 2 to 5 parliamentary factions. Both the conservative right and extreme left factions were small in this era, each ranging from 5 to $20 \%$ of the chamber, and correspondingly the Radical groups were the major force in the center. The Radicals as an ideological grouping held plurality, however, Radical groups were also the most heterogeneous and least organized (Hanley, 2006) - anywhere from 3 to 4 party groups would make up the Radical current. To measure centrist tendencies of deputies, we create an indicator variable, CEnTRIST, to measure whether a deputy had any affiliation with a Radical or Radical Socialist parliamentary grouping. Figure 1 demonstrates the breakdown of parliamentary current by our elite variables.

We also include a number of variables that could measure political influence. We look at the age of the deputy, AGE, as well as the parliamentary experience, ExP, of the deputy, both measured in years. Particularly in the early years of the regime, older deputies who had experienced the prior empire were more likely to be both privileged and of a different mindset than the younger, new republican generation. Prior experience is controlled for using whether the deputy was an INCUMBENT, or had served in the prior term, and whether the 


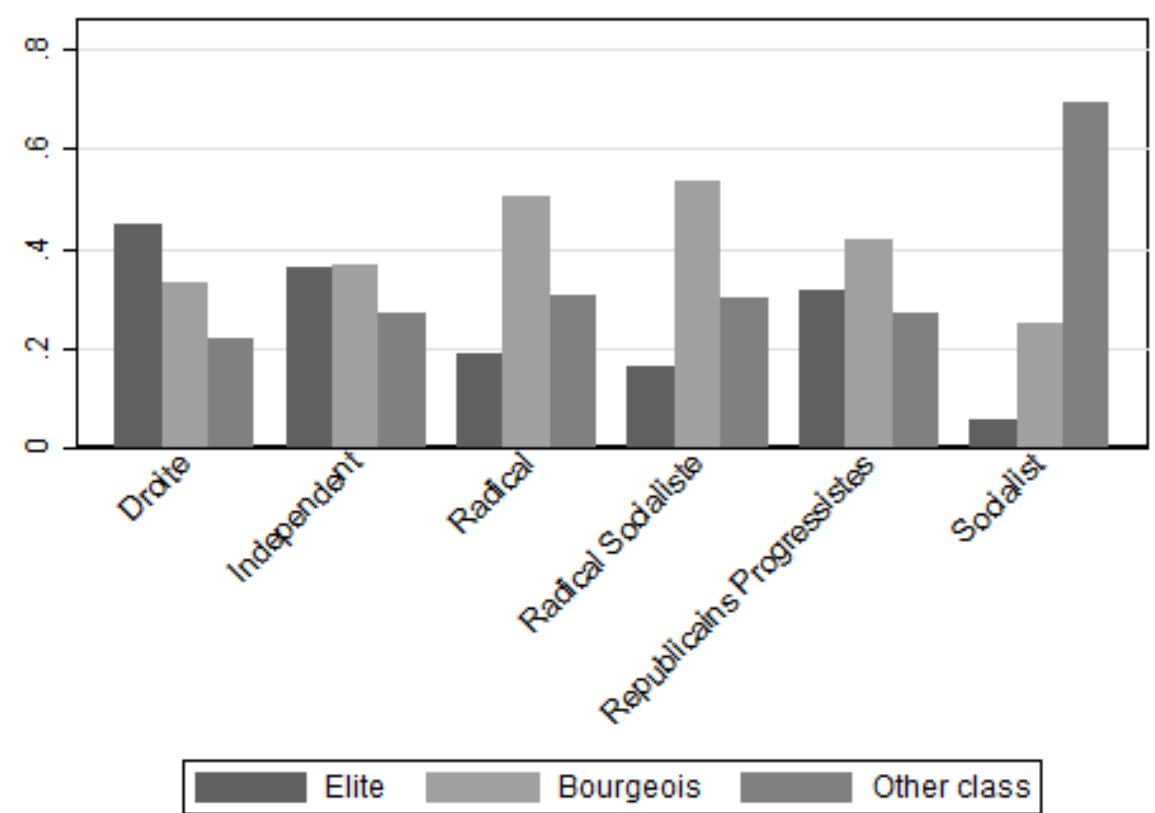

Figure 1: Deputy Type by Party Group

deputy was a Budget InCUMBEnT, and had served in the most recent budget committee.

We also rely on a measure of partisan behavior, by looking at the patterns of party switching for each deputy. Disloyal is an individual-level indicator that measures whether a deputy had switched parties in the 1906 term, right before the party reform gave control over budget appointments. Switcher is a variable that measures by term whether a deputy switched party groups in 1906 or in 1910 (compared to 1902). Access to political resources is measured using Dual MANDATE, or whether the deputy held a local office (such as mayor, or municipal councilor) in addition to his national post ${ }^{13}$ CiviL measures whether the deputy had prior experience in the civil service, such as serving as a tax collector, notary, postmaster, or any non-elected profession in local government, and DyNASTIC, measures whether a deputy had a relative in politics previously. Finally, we include a battery of district controls, including district size, margin of victory in the election, whether the district was in Paris.

\footnotetext{
${ }^{13} \mathrm{~A}$ dual mandate could give a deputy access to local patronage resources and a stable electoral base, see Author 2016.
} 
Table 1: Summary Statistics

\begin{tabular}{lrrrrrrrrr}
\hline & \multicolumn{3}{c}{ EliTe } & \multicolumn{4}{c}{ BourgeOIS } & \multicolumn{3}{c}{ OTHER ClAsSES } \\
& $\mathrm{N}$ & Mean & S.D. & $\mathrm{N}$ & Mean & S.D. & $\mathrm{N}$ & Mean & S.D. \\
\hline Civil $^{\dagger}$ & 5,068 & 0.14 & 0.35 & 9,971 & 0.12 & 0.33 & 9,610 & 0.18 & 0.38 \\
Dynastic $^{\dagger}$ & 5,068 & 0.30 & 0.46 & 9,971 & 0.17 & 0.38 & 9,610 & 0.17 & 0.37 \\
Paris $^{\dagger}$ & 5,068 & 0.02 & 0.15 & 9,971 & 0.06 & 0.24 & 9,610 & 0.11 & 0.31 \\
Centrist $^{\dagger}$ & 4,067 & 0.33 & 0.47 & 7,319 & 0.53 & 0.50 & 6,108 & 0.37 & 0.48 \\
Switcher $^{\dagger}$ & 5,068 & 0.15 & 0.35 & 9,971 & 0.15 & 0.36 & 9,610 & 0.11 & 0.31 \\
Disloyal (in 1906) $^{\dagger}$ & 190 & 0.28 & 0.45 & 379 & 0.21 & 0.40 & 221 & 0.15 & 0.36 \\
Dual mandate $^{\dagger}$ & 5,068 & 0.15 & 0.35 & 9,971 & 0.41 & 0.49 & 9,610 & 0.35 & 0.48 \\
Budget incumbent $^{\dagger}$ & 5,068 & 0.02 & 0.13 & 9,971 & 0.05 & 0.23 & 9,610 & 0.05 & 0.21 \\
Incumbent $^{\dagger}$ & 5,068 & 0.64 & 0.48 & 9,971 & 0.62 & 0.49 & 9,610 & 0.51 & 0.50 \\
Exp & 5,068 & 8.79 & 7.32 & 9,971 & 7.85 & 6.42 & 9,610 & 6.50 & 5.58 \\
Age & 5,068 & 52.79 & 11.14 & 9,971 & 49.51 & 10.83 & 9,610 & 51.44 & 10.66 \\
Electoral margin & 5,019 & 28.68 & 27.93 & 9,839 & 26.90 & 26.99 & 9,338 & 23.83 & 25.24 \\
Electorate (in 000s) & 5,023 & 27.68 & 35.92 & 9,863 & 29.60 & 47.07 & 9,358 & 39.53 & 73.72 \\
\hline
\end{tabular}

$\dagger$ indicates dummy variable.

Finally, any analysis of lottery-based rules requires the lottery to work, so we also verified that the randomization process was correctly implemented. A more detailed discussion of the finding that the deputies were truly randomly assigned across bureaux can be found in $\mathrm{Au}-$ thors (2016). We executed a number of robustness checks to ensure bureaux were randomly assigned. We find no systematic differences across bureaux, and pretreatment covariates cannot systematically predict bureaux assignment. Furthermore, there is no historical evidence to suggest any occasions of fraud regarding the bureaux system.

\subsection{Budget Composition Under Bureaux}

We are first interested in the types of politicians selected for the budget committee as a result of the bureaux system. We first show this by comparing the composition of the budget committee to the legislature, across the entire period in which the bureaux system was utilized. In the absence of a lottery-based procedure, our expectation is that endogenous selection should prioritize the "high demander" outliers (Rowley and Schneider, 2008), in our case either experienced or wealthy elites who would have a distinct advantage in competing 
for office. Instead, we show that incorporating an element of randomization results in the selection of different types of politicians.

Using our data, we consider descriptive statistics. Figure 2 plots the composition of the budget committee and the composition of the entire chamber, over a number of key characteristics of deputies. It is evident that the budget committee overrepresented middle class, bourgeois deputies - not elites. Landed elites constituted anywhere from 10 to $30 \%$ of deputies in the chamber, but on average constituted less than $10 \%$ of the budget committee. Similarly, older deputies, who were more likely to be associated with the pre-democratic empire, were much less likely to be selected, as were deputies with patronage networks through multiple office holding. Instead, selection in the bureaux overrepresented deputies who were middle class, young, and had prior experience in the local government.

Next we examine how the bureaux system affected the partisan composition of the budget committee. One of the purported benefits of the bureaux system was that one parliamentary faction could not dominate the selection process. Looking at the data across the entire period, we find this to be the case. The centrist, Radical deputies were more likely to be on the budget committee under the system of bureaux. However, these parties were also the least organized and most heterogeneous at the time, typically consisting of 3-4 factions within the Radical ideological bloc. So while one specific faction was unable to dominate the committee, the median and centrist ideological bloc was overrepresented.

This result contradicts the expectations of the time. Usher (1902), for example, argued the budget committee was "more or less out of sympathy" with the majority, because the system could not ensure the majority could control the committee. We show that instead, groups in the plurality of the chamber were more likely to be selected in the bureaux. But what advantaged centrist deputies in committee selection? Details surrounding selection within the bureaux were never recorded, and so the specifics of selection are unknown. However, it seems likely that centrist deputies could more easily appeal to the cross section of deputies within each bureaux. As a result, this might explain why the budget committee overrepresented centrist preferences. 


\section{Elite}

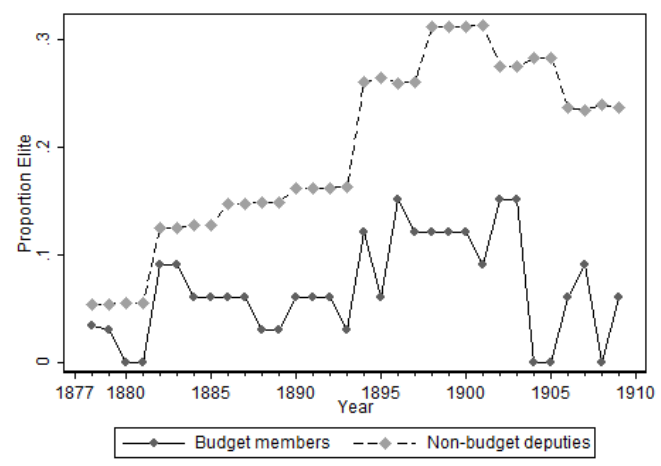

Bourgeois

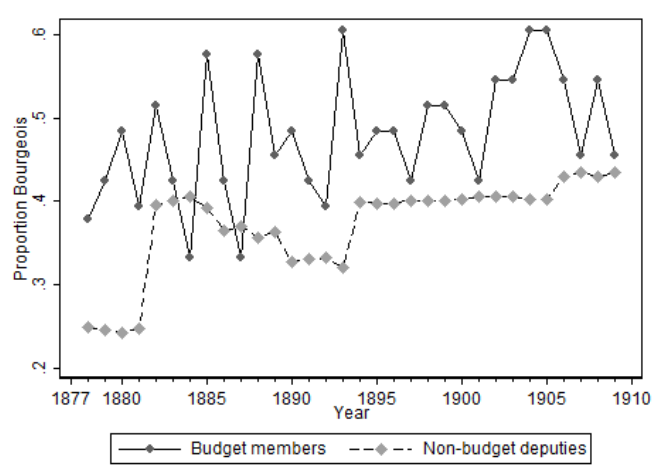

Age

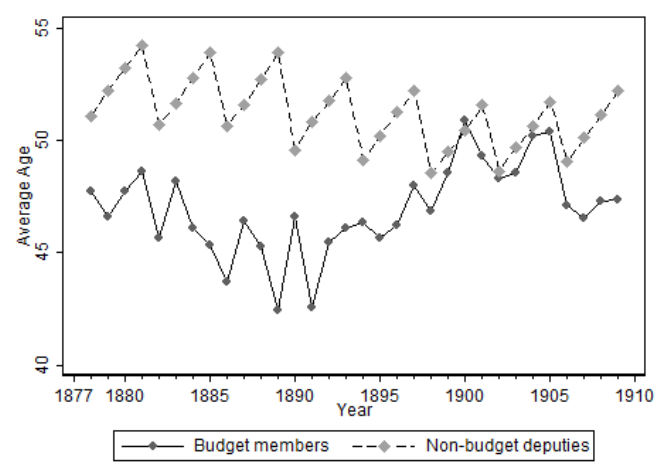

Dual Mandates

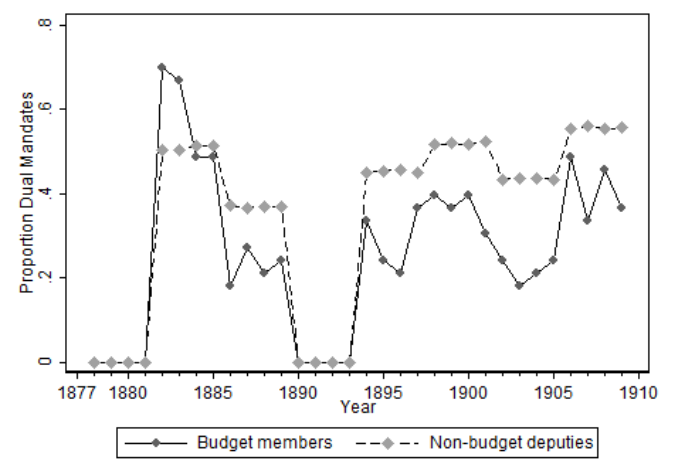

Civil Service

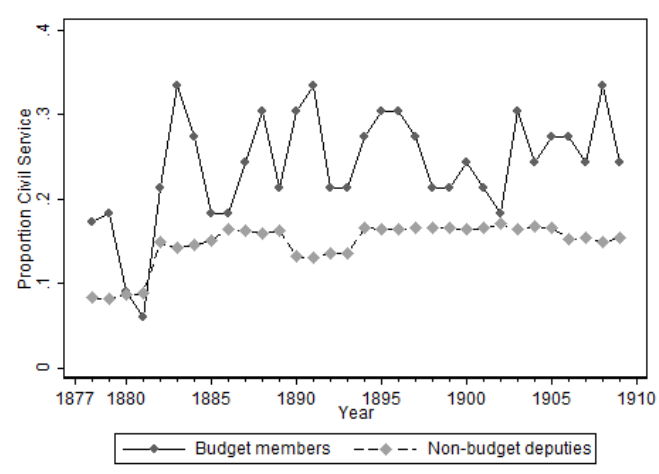

Centrist (Radical) Deputy

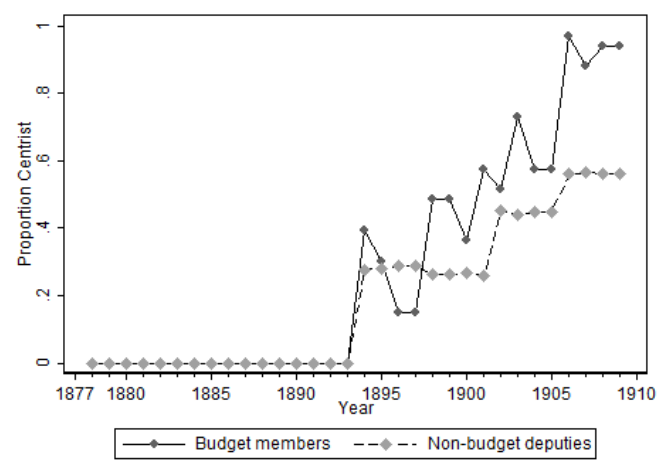

Figure 2: Deputy Characteristics, Chamber versus Budget Committee Under Bureaux 
However, for this period we have no counterfactual. It could be that lottery-based procedures were eroding elite advantage and allowing the newer political class the ability to compete, or rather this was the preferences of the chamber at the time. We try to unpack this by next looking at how selection changed in 1910, when parties gained control over committee assignments.

\section{Empirical ANALYSis}

In this section, we explore the relationship of the bureaux system to French political parties in two ways. First, we examine partisan incentives behind institutional reform using an roll call analysis of the 1910 amendment that dismantled the lottery-based procedure. Second, we look at the the effects of partisan control on committee selection, to understand how the composition of the budget committee changed before and after partisan control.

\subsection{Empirical strategy}

To study our arguments, we now analyse the French case in more detail. First, we ask who was in favour of reforming the system to abolish the lottery-based procedure. We argue that those deputies who are organised and believe their party stands to gain from controlling committee appointments, will vote in favour of the reform. Therefore, we analyse the roll call vote on the reform bill, and because the dependent variable is a dummy (vote in favour of reform) we employ a logistic regression with or without a deputy's 1910 partisan affiliation. Standard errors are robust. If our hypothesis holds, partisan affiliation should form a very strong predictor of a deputy's vote, regardless of his individual characteristics. Next, we analyse the partial association between any individual characteristic and budget committee selection, before and after the 1910 reform. Our expectation is that selection is more egalitarian before parties gain control over the nomination process, or that elites and bouregeois politicians become more likely to be selected after 1910. Again, we estimate the appropriate logistic regression, and because individual characteristics cannot change over time we cluster the standard errors by individual. 
If our hypotheses about political selection under different selection procedures holds, we should see that individual selection probabilities change after parties gain control over nominations. We expect these probabilities to become less equal after the lottery-based procedure is abolished. We expect parties to give preference to more loyal elite members after they gain control. To further test this hypothesis about the selection of loyal members, we consider a sample of deputies who were present in both the 1910 term and the preceeding term of 1906. We then compare their partisan affiliations in 1906 to their affiliation(s) in 1902. We hypothesise that the group of disloyal deputies, who changed affiliations between 1902 and 1906, is less likely to be selected after 1910, when parties gain control, than before under the more egalitarian lottery-based procedure. We test this hypothesis with a differencein-difference analysis, using a logistic regression with individually clustered standard errors.

\subsection{Results: Determinants of Support for Bureaux Reform}

In 1910, the bureaux system was dismantled and replaced with the election of the budget committee via party-controlled lists. Opponents of reform submitted a blocking amendment that would preserve the lottery-based procedure, but this failed 196 to 300, and therefore paved the way for partisan control of committee selection. As the vote on this bill was a roll call vote, we can examine how deputy characteristics and party affiliations predicted support for reform. For a more intuitive interpretation of this blocking amendment, we rescale the indicator variable such that 1 indicates a vote in support of partisan control and 0 indicates a vote in support of retaining the bureaux system.

Table 2 presents the results of two logit models, in which we estimate the effect of belonging to one of the five ideological blocs on voting to dismantle the bureaux system ${ }^{14}$ Given the rationale for lottery-based parliamentary procedures was to protect the institution from weak or self interested factions, then it follows that their removal is related to partisan preferences. In column 1, we see some effect of individual deputy characteristics, but most disappear when controlling for partisan group affiliation.

\footnotetext{
${ }^{14}$ The results are the same when controlling for the ten parliamentary groups that made up the five ideological blocs.
} 
Table 2: Logit Regression: Roll Call Vote of 1910 Reform

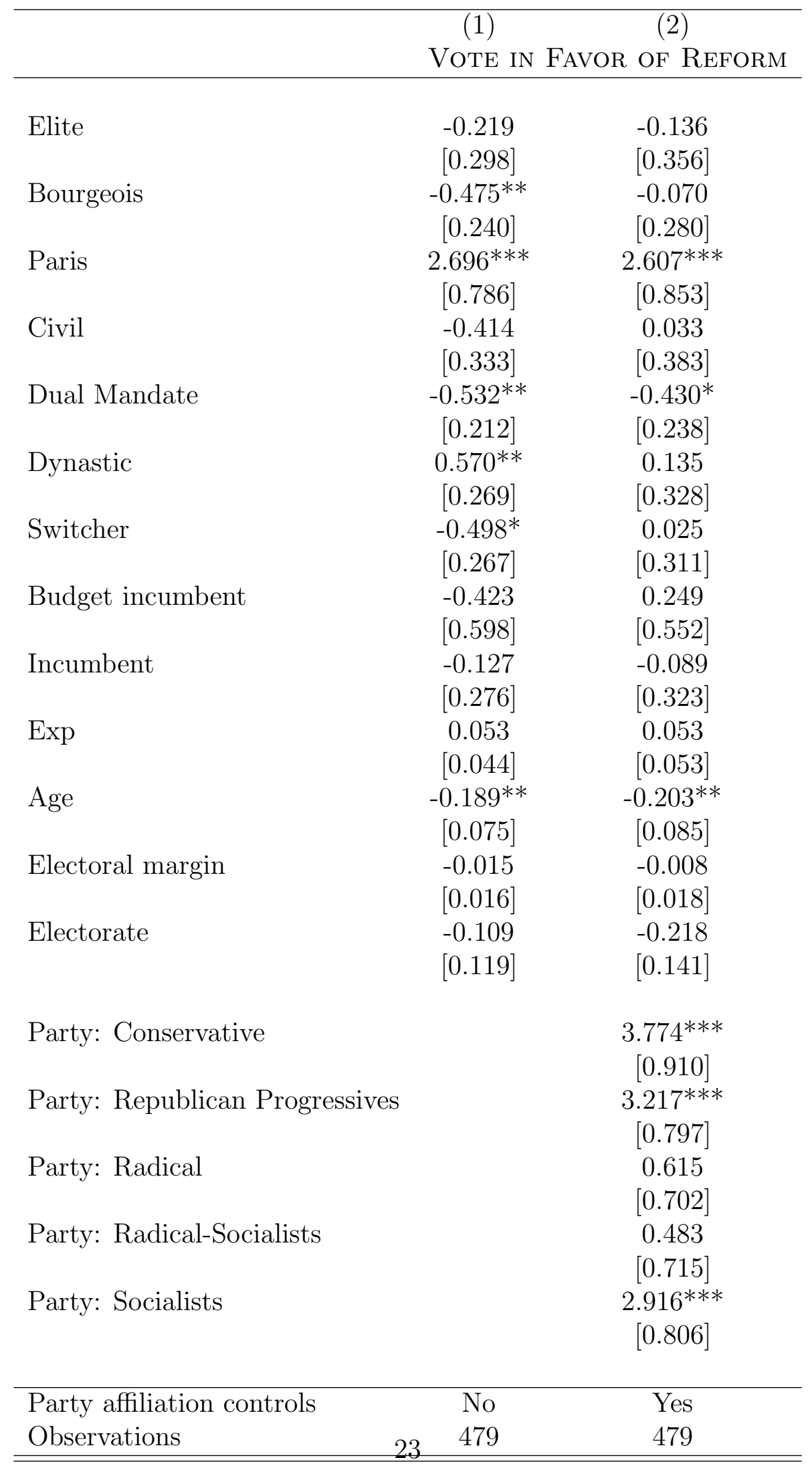

Logit regression. Individual controls as in 1 , with the exception of centrist to explore party differences. Base category for party affiliation is independents. Controls not shown include the squared terms of age, experience, electoral margin, and electorate. Robust standard errors. ${ }^{* * *} \mathrm{p}<0.01,{ }^{* *} \mathrm{p}<0.05,{ }^{*} \mathrm{p}<0.1$. 
In 1910, the distribution of the chamber by bloc was as follows: Conservatives 9\%, Progressives 13\%, Radicals 32\%, Radical Socialists 25\%, Socialists 19\%, and Independents $3 \%$. Radicals and Radical-Socialists comprised the majority of the seats, meaning they would be decidedly advantaged in proportional allocation of committee posts. Yet Radicals and Radical-Socialists were against and smaller groups were in favor of reform. Both specifications show that being a member of the Conservatives, Progressives, and Socialists results in a double or even triple increase in the odds of voting in favor of partisan control.

However, it was well known at the time that the smaller groups on each edge of the ideological spectrum were much more cohesive and organized than the heterogeneous centrist groups in the middle (Hanley, 2006). The Conservative and Socialist factions were consistently and clearly defined, with stable membership and high internal organization. In contrast, while Radicals were guaranteed a larger number of committee posts to allocate, their fluid membership and lack of formal governing structures meant higher uncertainty and perhaps an inability to properly utilize such a selective incentive. The Radicals and the Radical Socialists had seen the highest number of group reconfigurations in the terms preceding 1910, and there was still shifting membership across centrist factions.

Thus we find the more organized and cohesive the party, the less likely its members are to favor a lottery-based procedure. Furthermore, as presented in the previous section, centrist deputies were overrepresented under the bureaux. This could explain why Radical groups were not more likely to vote for the reform - they did not want to relinquish control to party organizations, because they were advantaged by the lottery-based procedure.

\subsection{Results: Selection Under Partisan Control}

Here we present further results that demonstrate that lottery-based procedures induced different selection criteria, by comparing it to an alternative selection mechanism - partisan control. Here we can compare the selection of the budget committee in 1906 term (under lottery-based procedure) to 1910 (when parties chose budget committee members). We focus on a relatively short window, the term before and the term of the change, to see whether 
elites were more likely to be appointed by party leaders 15

Figure 3 plots the estimates for interactions between our variables of interest with an indicator for the 1910 term. Each interaction measures the marginal change in the probability of being selected to the budget committee in 1910 after partisan control, given the characteristic. The key finding from this analysis is that elites were much more likely to be appointed under partisan control. While the bureaux system undermined the selection of elites, partisan control increased the likelihood of their selection. Bourgeois deputies were still likely to be selected, but this effect is much weaker and deputies with civil service experience has no effect on the probability of serving on the budget committee. Unsurprisingly, centrist deputies are less likely to be selected, because the proportional allocation of committee posts based on party strength ensures minorities are going to be represented. Still, as a result of partisan control, Radical deputies lost some of their influence in the process of institutional reform.

These results demonstrate the difference between lottery-based procedures and partisan selection outcomes. Once parties gained control of committee assignments, the types of politicians appointed changed and elites returned to influential positions of power.

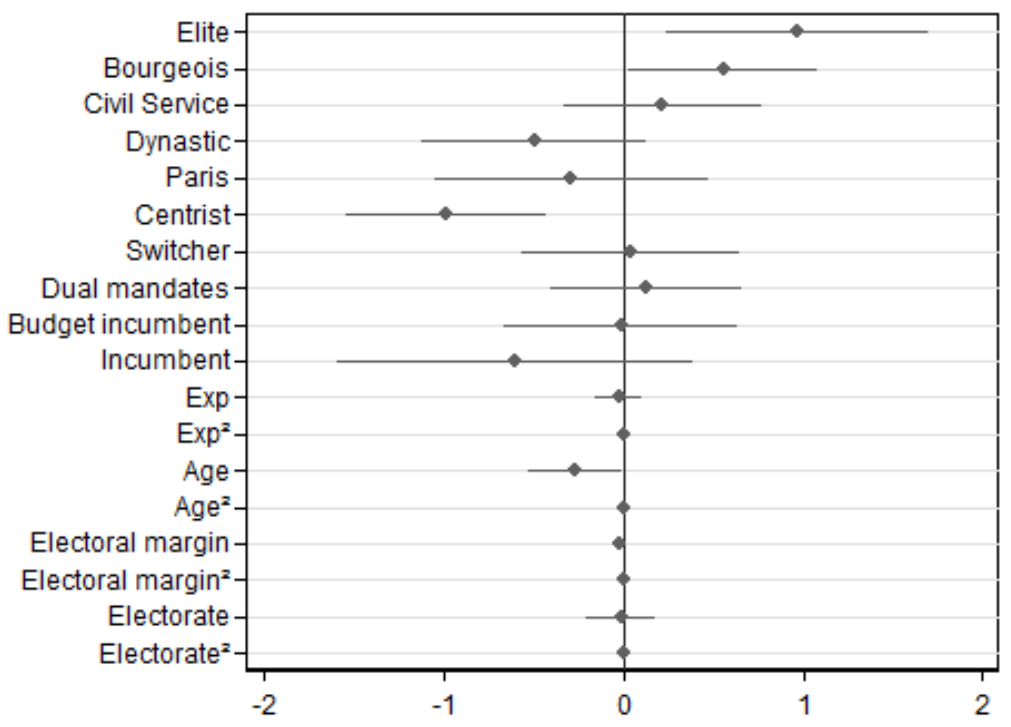

Figure 3: Change in Pr. of Budget Committee Selection Compared to 1906

\footnotetext{
${ }^{15}$ We do not look past the 1910 term because by 1914 parliamentary politics was significantly affected by World War I, and by 1919 the electoral law had been changed.
} 


\subsection{Results: Committee Assignments and Party Loyalty}

Our evidence thus far has demonstrated that the bureaux system disadvantaged elites, and overrepresented young, skilled members of a rising political class, which may indicate the benefits of a lottery-based procedure. But does this come at a cost for party development? Or, put another way, does partisan selection potentially benefit political parties?

Finally, we turn to a behavioral measure to analyze how parties may have utilized committee posts as selective incentives. We use the DisLOYAL variable, which measures whether a deputy switched party affiliation in the 1906 term before the reform, to see if parties reward those deputies who had joined their party before the reform, by selecting them onto the budget committee.

We conduct a simple difference-in-difference comparison for those deputies whom we observe over both the 1906 and the 1910 term. We then compare those who changed their affiliations before 1910 to those who did not (DiSLOYAL). Both groups were subject to the same treatment by which parties took control over nominations in 1910. We can only look at one term before the onset of the first World War, but the results are suggestive even in a short time span: parties did not reward deputies who had not been loyal to their party affiliations once they received control over appointments.

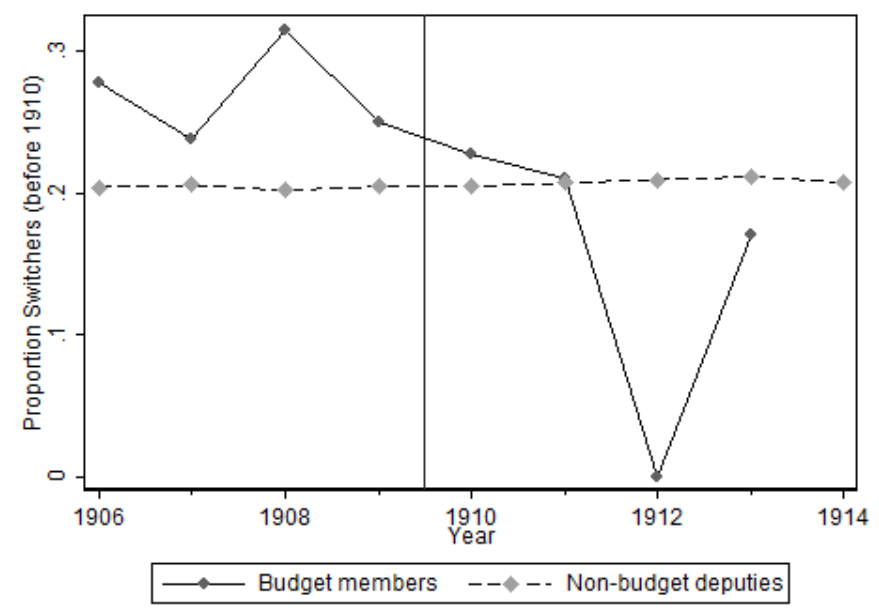

Figure 4: Change in Selection probability for Disloyal deputies (in 1906) in 1910 
Table 3: Logit Regression: Party Loyalty and Budget Selection

\begin{tabular}{lccc}
\hline & $(1)$ & $(2)$ & $(3)$ \\
& & BuDGET & \\
\hline & & & \\
Disloyal in 1906 & $-0.780^{* *}$ & $-1.271^{* *}$ & $-1.176^{*}$ \\
$\times$ after 1910 & {$[0.364]$} & {$[0.642]$} & {$[0.698]$} \\
Disloyal in 1906 & $0.613^{*}$ & 0.693 & 0.565 \\
& {$[0.360]$} & {$[0.451]$} & {$[0.512]$} \\
after 1910 & $0.780^{* * *}$ & $0.977^{* * *}$ & $39.153^{* * *}$ \\
& {$[0.180]$} & {$[0.293]$} & {$[7.092]$} \\
& & & \\
Constant & $-2.282^{* * *}$ & -1.925 & $-32.897^{* * *}$ \\
& {$[0.195]$} & {$[2.788]$} & {$[6.447]$} \\
\hline Individual controls & No & Yes & Yes \\
Party group dummies & No & Yes & Yes \\
Party group dummies, all interactions after 1910 & No & No & Yes \\
Observations & 790 & 787 & 787 \\
\hline \hline
\end{tabular}

Logit regressions. Individual controls as in 1, with the exception of switcher. Base category for party affiliation is independents. Column 3 includes all interactions with controls and dummies after 1910. ${ }^{* * *} \mathrm{p}<0.01,{ }^{* *} \mathrm{p}<0.05,{ }^{*} \mathrm{p}<0.1$.

Figure 4 and Table 3 show the results of this difference-in-difference comparison. We find that party groups were less likely to appoint disloyal deputies to the budget committee, indicating that parties perhaps used their newfound ability to reward loyal deputies instead. Also note that this analysis only includes deputies who had been present in both the 1906 and 1910 terms; so this is not picking up party preferences towards first time deputies.

This might suggest there are clear tradeoffs between lottery-based procedures and partisan selection. Committee assignments are an important asset in the parliamentary arena, and can be used by party groups as selective incentives to achieve discipline in voting or membership. Stripped of such tools, early parties may find it more difficult to induce party cohesion among members. The fact that parties were more likely to appoint loyalists suggests that parties were using committee assignments as such. Our evidence is only suggestive; both the small time frame and changing parliamentary activity due to World War I make it difficult to test whether parties continued to use committee assignments as selective incentives. But this could indicate a tradeoff in the use of lottery-based procedures in early party 
development. We leave this for future research.

\section{Lottery-Based Procedures in $19^{\mathrm{TH}}$ Century Europe}

A number of European countries incorporated lottery-based procedures in nascent committee systems, in their early stages of parliamentarization. This includes the Netherlands, Imperial Germany, and the Austrian empire, in legislative bodies under monarchies; Denmark, in the case of its constitutional convention; and of course France, in its transition to to republican democracy. Like France, each country faced similar political challenges during the course of parliamentarization. Each featured highly fragmented or weak party systems, during significant periods of institutional development. Importantly, in every single country institution builders incorporated lottery-based procedures in committee systems out of a distrust for potentially subversive political factions or influential elites. As a result, the use of such rules were inextricably linked with concerns about institutional capture by political parties or factions. While suggestive, our broad survey suggests that lottery-based procedures were used to reduce the influence of elite cartels and then eventually removed with the development of organized parties.

In Denmark, a lottery-based procedure was adopted in the case of its Constituent Assembly of 1848-1849, which resulted in the creation of the constitution that still governs Denmark to this day. A lottery selected general committees in the Assembly, which helped develop the initial constitutional proposal and selected members to the powerful Constitutional Committee (Hansen 2016). Here, there is historical evidence that the adoption of the procedure stemmed from the weakness of the party system, and a desire to ensure fairer representation of various democratic factions in the building of the constitution. At the time, there existed up to 11 parties (Olsen 1972; Hansen 2016) organized into political blocs. The lottery based procedure was adopted to prevent the concentration of political blocs into any one committee, particularly the radical and pro-democratic left, and therefore prevented co-optation of the Constitution Committee (Hansen, 2016). This strategy was successful, and - similar to the French case - partial randomization ensured a newly formed center played a more dominant part in the proceedings. In this, lottery based procedures succeeded in playing a temporary but sanitizing role in the creation of the Danish constitution. 
Table 4: $19^{\mathrm{TH}}$ Century European Examples

\begin{tabular}{|c|c|c|c|}
\hline COUntry & Time Period & Procedure & Context \\
\hline France & $\begin{array}{l}\text { Third Republic (1870- } \\
\text { 1940) }\end{array}$ & $\begin{array}{l}\text { Each MP randomly assigned to } \\
\text { groups (Bureaux), to then select } \\
\text { committee members }\end{array}$ & $\begin{array}{l}\text { Weak parties, fear of } \\
\text { factions }\end{array}$ \\
\hline Germany & $\begin{array}{ll}\text { German } & \text { Empire } \\
(1871-1918) & \end{array}$ & $\begin{array}{l}\text { Each MP randomly assigned to } \\
\text { groups (Abteilungen), to then se- } \\
\text { lect committee members }\end{array}$ & Fear of factions \\
\hline Denmark & $\begin{array}{l}\text { Constituent Assembly } \\
\text { (1848) }\end{array}$ & $\begin{array}{l}\text { Lottery selected deliberation } \\
\text { committees, to then select Con- } \\
\text { stitutional Convention members }\end{array}$ & $\begin{array}{l}\text { Weak parties, fear of } \\
\text { Left dominance }\end{array}$ \\
\hline Austria & $\begin{array}{l}\text { Austrian-Hungarian } \\
\text { Empire (1875) }\end{array}$ & $\begin{array}{l}\text { Each MP randomly assigned to } \\
\text { groups (Abteilungen), to then se- } \\
\text { lect committee members }\end{array}$ & $\begin{array}{l}\text { Multi-partyism and } \\
\text { ethnic divisions }\end{array}$ \\
\hline Netherlands & $\begin{array}{l}\text { Constitutional } \\
\text { Monarchy (1815) }\end{array}$ & $\begin{array}{l}\text { Each MP randomly assigned to } \\
\text { groups (Afdelingen) to study and } \\
\text { report on legislative proposals }\end{array}$ & $\begin{array}{l}\text { Fear of provincial fac- } \\
\text { tions and dominance } \\
\text { of specialists }\end{array}$ \\
\hline
\end{tabular}

Austria, even more so than Denmark, had issues with extreme multipartyism, and also turned to lottery based procedures. As Lowell wrote, "If France has been a laboratory for political experiments, Austria-Hungary is a museum of political curiosities." The empire consisted of provinces that had no natural coherence, and the population consisted of a multitude of ethnic and nationalist divisions. As a result, Austria was a case of extreme multipartyism for example, in 1907 there were 58 parties elected that formed 19 parliamentary clubs (Howe, 2010). The historical record indicates a strong need for institutional rules that mitigated the contextual challenges. In Austria, a lottery-based procedure was adopted in committee selection for the lower house of the the parliament, the Reichsrat, founded in 1867 ${ }^{16}$ The

\footnotetext{
${ }^{16}$ This was a result of a compromise that established the dual monarchy of the kingdoms of Austria and Hungary.
} 
legislature was divided into nine groups (Abteilungen) by lot, chosen at the beginning of the legislative session, and then these groups each elected an equal number of members to the various standing committees (Howe, 2002). Thus the committee system was structured in a way to remove partisan influence over appointments, and to ensure that one party or coalition could not suppress minority factions. The fractionalized party system persisted for the duration of the empire, and parties never truly consolidated, which can help to explain why the lottery-based procedure remained in place until the first decade of the 20th century.

The Dutch case also used lottery based procedures in legislative committees for an extended period of time. In the Netherlands, the use of randomization in committees predates democratization (Hagelstein 1991). The 1815 constitution dictated that all legislative proposals from the king and his ministers should be studied by parliament organized in randomly assigned groups, called Afdelingen. The 5 divisions would both discuss proposals and nominate a representative to a Central Bureau, Centrale Afdeling. After partial democratization in 1848 , this system remained in place because of the fear that without the groups experienced or skilled deputies would dominate legislative procedure. The first formally organized, national party was not established until 1879, but party factions remained weak and randomly drawn groups existed well into the mid 20th century. Similar to the case of France, the lottery-based procedure was implemented during party fragmentation and endured for a significant period of time.

In contrast, Germany attempted to utilize lottery based procedures but these were dismantled quickly by relatively organized parties. Germany implemented lottery-based committee selection in the Reichstag, the parliament of the German Empire from 1871 to 1918. Procedures in the Reichstag called for dividing the parliament into five divisions by lot, and these groups would then appoint members to legislative committees (Loewenberg, 2003). This procedure had been adopted explicitly to 'circumvent' party groups; Abteilungen were intended to be representative and political neutral units (Manow, Schroeder and Nickel, 2011). Yet while parties, or Fraktionen, were not formally recognized in parliament until 1922, constitution builders were extremely wary about the dangers of party factions. As a result, while the procedures had been adopted to prevent elite capture, groups almost immediately began to subvert committee selection. There is historical evidence that factions 
played an informal role in selection criteria for appointment within the Abteilungen, along with regional provenance and religious affiliation (Wittreck 2007). Consequently, the institution existed for a very short period of time - by 1893, organized parliamentary groups abolished the lottery based procedure, and succeeded in reforming the law to distribute committee assignments in proportion to party strength.

These 19th century examples demonstrate the strategic use of lottery-based procedures in $19^{\text {th }}$ century European committees. In all countries, decisive actors were concerned about the co-option of the institutions by partisan factions in the context of either weak or divisive party systems. The historical record suggests that this was generally successful. Lotterybased procedures helped protect the Danish constitution from co-optation by the overly radical left, in all likelihood provided Austria with a way to manage extreme multipartyism, and provided a framework for committee selection in the absence of strong parties in France and regional interests in the Netherlands for decades.

Lottery-based parliamentary procedures also interacted with party development, in that the adoption or dissolution of such procedures related to the consolidation and strength of parliamentary groups. Initially weak parties enabled a system of divisions to exist for what would eventually become over a century in the Netherlands. In France, the dismantling of the bureaux system coincides with party consolidation. In the contexts of Germany and Austria, both were monarchies with similar institutional structures but saw divergence in the organization of groups in parliament - Germany's parties quickly removed the lottery based procedure, while Austria's fractionalized party system kept these rules in place until the 20th century. This cross national evidence is suggestive, and points to an important role of lottery-based procedures in regulating legislative activity, until parties are cohesive enough to take over.

\section{Conclusion}

In this paper, we have studied the use of lottery-based rules in newly formed legislative institutions during the process of parliamentarization in Europe. In the case of the French Third Republic, we presented evidence that partial randomization in budget committee 
selection process resulted in the appointment of young, skilled, middle class deputies at the expense of influential elites. However, once party groups regained control of committees in 1910, elites were more likely to be appointed to the budget committee. We also showed that both the use and dismantling of this system was related to partisan politics; cohesive parties were more likely to vote for the dismantling of the bureaux system, and we provide evidence that parties used their newfound influence to reward loyal members with committee assignments.

We then reviewed the use of such procedures in the 19th century cases of Germany, Austria, Denmark, and the Netherlands. We showed that these countries had fledgling party systems and incorporated various selection by lot in legislative committees, and that the abolishment of such procedures was linked with the consolidation of parliamentary factions. In these countries, during democratic transitions parties chose a system that guaranteed a certain level of representation rather than dealing with the uncertainty of who would be in power. These examples parallel the French case, and provide further evidence that the rationale behind the use of such procedures related directly to stability in early parliamentarization.

Understanding the role of lottery-based procedures in committee selection is an important avenue for future research. For example, in the European cases presented here we discussed how lottery-based procedures were used to form groups to deliberate over legislative policy. This relates directly to a number of studies that have suggested sortition can be used in the context of deliberative groups. Randomly assigned focus groups (in the UK, see Goodin, 2008) or deliberative polling (Fishkin, 2011) were found to be equally capable of analyzing the quality of public policy as elites. More broadly, our findings speak to a bourgeoning literature on the use of sortition outside of parliament, in the electoral arena. In modern democracies, sortition is now being considered as a solution to democratic deficits or the perils of direct democracy (Van Reybrouck, 2016). We have argued that strong parties are unlikely to favor sortition and that such procedures, when implemented, could quickly lead to the more organised party factions striving for control over policy formation.

Finally, an interesting result from the French case is that it suggests there are clear tradeoffs between lottery-based procedures and partisan selection. Committee assignments 
can be an important tool, used by political parties to reward loyal members and develop long term cohesion. In the French case, while we show that party groups were more likely to select elites for the budget committee, we also provide suggestive evidence that they used committee posts to reward loyal members. Thus the advantage of lottery-based procedures might be most salient in contexts of weak parties and developing institutions; used to bridge the gap until the regime is stable and political parties are consolidated enough to use the selective incentives inherent in committee posts. 


\section{References}

[1] Abramson, Scott. 2016, "The Economic Effects of Leaders' Economic Interests: Evidence from Election By Lot in the Florentine Republic." Working Paper.

[2] Broockman, David and Daniel Butler. 2015. "Do Better Committee Assignments Meaningfully Benefit Legislators? Evidence from a Randomized Experiment in the Arkansas State Legislature." Journal of Experimental Political Science, 2 (2): 152-163.

[3] Barnett, A., and Carty, P., 1998 [2008]. The Athenian option. Radical reform for the House of Lords. Charlottesville: Imprint Academic.

[4] Bodley, John E.C. 1898. France, Volume II, Book III: The Parliamentary System. London: MacMillan and Co.

[5] Bowler, Shaun. 2010. "Private Members' Bills in the UK Parliament: Is There an Electoral Connection?" The Journal of Legislative Studies, 16 (4): 476-494.

[6] Buchstein, Hubertus and Michael Hein. 2009. "Randomizing Europe: the lottery as a decision-making procedure for policy creation in the EU," Critical Policy Studies, 3:1, $29-57$.

[7] Capoccia, Giovanni and Daniel Ziblatt. 2010. "The Historical Turn in Democratization Studies: A New Research Agenda for Europe and Beyond." Comparative Political Studies, 43: 931.

[8] Cole, Alistair and Peter Campbell. (1989). French Electoral Systems and Elections since 1789. Gower, Aldershot: New York.

[9] Colomer, Josep. 2014. How Global Institutions Rule the World. Palgrave Macmillan US.

[10] Dawson, Philip. 1972. Provincial Magistrates and Revolutionary Politics in France, 1789-1795. Harvard University Press.

[11] Dogan, Mattei. 1979. "How to Become a Cabinet Minister in France: Career Pathways, 1870-1978." Comparative Politics, 12 (1): 1-25. 
[12] Dowlen, Oliver. 2009. "Sorting Out Sortition: A Perspective on the Random Selection of Political Officers." Political Studies, Vol 57, 298-315.

[13] Duverger, Maurice. 1954. Political Parties. London: Methue.

[14] Eggers, Andrew C. and Spirling, Arthur. 2014. "Guarding the Guardians: Legislative Self-policing, Corruption and Judicialization in Victorian Britain" Quarterly Journal of Political Science, 9: 337-370.

[15] Engelstad, Fredrik. 1989. "The assignment of political office by lot." Social Science Information, vol. 28 no. 1, 23-50.

[16] Fishkin, James. 2011. When the people speak: Deliberative democracy and public consultation. Oxford University Press.

[17] Frederiksen, Oliver. "The Bureaus of the French Constituent Assembly of 1789." Political Science Quarterly, Vol. 51, No. 3. (Sep., 1936), pp. 418-437.

[18] Gooch, R. K. 1928. "The French Parliamentary Committee System." Economica, 23 (June): 147-158.

[19] Grimmer, Justin and Eleanor Powell. 2013. "Congressmen in Exile: The Politics and Consequences of Involuntary Committee Removal." The Journal of Politics, 75 (4): 907-920.

[20] Hagelstein, GH. 1991. "De parlementaire commissies", Nederlands Parlementsrecht Monografie 6. Groningen: Wolters-Noordhoff.

[21] Hanley, D. 2006. Party, Society, Government: Republican Democracy in France. Berghahn.

[22] Hansen. Martin. Working Paper 2016. "Institutional Design under Weak Parties: Voting Behaviour in the Danish Constituent Assembly 1848-1849."

[23] Howe, Philip J. Well-Tempered Discontent: nationalism, ethnic group politics, electoral institutions and parliamentary behavior in the Western half of the Austro-Hungarian Monarchy, 1867-1914. Ph.D. Diss. University of California at San Diego, 2002. 
[24] Howe, Philip J. 2010. "Electoral Institutions and Ethnic Group Politics in Austria, 1867-1914." Nationalism and Ethnic Politics, 16.2.

[25] Hubertus, Buchstein Michael Hein. 2009. "Randomizing Europe: the lottery as a decision-making procedure for policy creation in the EU." Critical Policy Studies, 3:1, $29-57$.

[26] Journal Officiel. Parliamentary debates, July 1, 1910. Accessed using BnF: Gallica.

[27] Kellermann, M. and Shepsle, Kenneth. 2009. "Congressional Careers, Committee Assignments, and Seniority Randomization in the US House of Representatives." Quarterly Journal of Political Science, 4: 87 -101.

[28] Koole, Ruud. 1995. "Politieke Partijen in Nederland: Ontstaan en ontwikkeling van partijen en partijstelsel", Utrecht: Het Spectrum.

[29] Krehbiel. 1993. "Where's the party?" British Journal of Political Science, 23: 235-66.

[30] Levitsky, S. and Cameron, M. A. (2003), Democracy Without Parties? Political Parties and Regime Change in Fujimori's Peru. Latin American Politics and Society, 45: 1-33.

[31] Loewenberg, Gerhard. 2003. "Agenda-setting in the German Bundestag: origins and consequences of party dominance." The Journal of Legislative Studies, 9:3, 17-31.

[32] Loewen, Peter John, Koop, Royce, Settle, Jaime and Fowler, James H. 2014. "A Natural experiment in proposal power and electoral success," American Journal of Political Science, 58:1, 189-196.

[33] Lopez-Guerra, Claudia. 2010. "The enfranchisement lottery." Politics, Philosophy and Economics, 000 (00), 1-23.

[34] Lowell, Abbot Lawrence. 1896. Governments and parties in continental Europe. Boston and New York, Houghton, Mifflin and company.

[35] Lupu, N. and Riedl, R. (2013). Political Parties and Uncertainty in Developing Democracies. Comparative Political Studies 46 (11). 
[36] Mainwaring, Scott and Timothy R. Scully. 1995. Building Democratic Institutions: Party Systems in Latin America. Stanford: Stanford University Press).

[37] Manin, Bernard. 1997. The Principles of Representative Government. New York: Cambridge University Press.

[38] Manow, Philip, Valentin Schroeder and Carsten Nickel. Working paper, 2011. Germany's 1918 electoral reform and the Reichstag's 'Efficient secret.'.

[39] Mill, John Stuart. 1848. "Vindication of the French Revolution of February, 1848." In Dissertations and Discussions: Political, Philosophical, and Historical. Volume III. New York: Henry Holt and Company.

[40] McPhee, Peter. 2004. A Social History of France, 1789-1914. Second edition, Palgrave Macmillan.

[41] Olsen, P. N. 1972. "At the Cradle of a Party System: Voting Patterns and Voting Groups in the Danish Constitutional Convention 1848-1849." Scandinavian Political Studies, 7: 119-135.

[42] Pippel, J.G. 1950. Het Reglement van Orde van de Tweede Kamer der Staten-Generaal zijn Geschiedenis en Toepassing 's-Gravenhage: Staatsdrukkerij en Uitgeverijbedrijf.

[43] Price, Roger. 1987. A Social History of Nineteenth-Century France. Bloomsbury Academic.

[44] Probyn, J. W. (ed.). 1877. Correspondence Relative to the Budgets of Various Countries. London: Cassell Petter and Galpin.

[45] Rasch, Bjorn Erik. 1995. "Parliamentary Voting Procedures" in Parliaments and Majority Rule in Western Europe, edited by Herbert Doring. Palgrave MacMillan.

[46] Rowley, Charles and Friedrich Schneider. 2008. The Encyclopedia of Public Choice. Springer Science Business Media.

[47] Stone, Peter. 2009. "The Logic of Random Selection." Political Theory, Volume 37 Number 3. 
[48] Sutherland, K. 2004. The Party's Over. Exeter: Imprint Academic.

[49] Taylor, C. 2007. "From the whole citizen body? The sociology of election and lot in the Athenian democracy." Hesperia, 76, 323-346.

[50] Tridimas, George. 2012. "Constitutional choice in ancient Athens: the rationality of selection to office by lot." Const Polit Econ, 23:1-21.

[51] Usher, Abbott Payton. 1906. "The Reform of Procedure in the French Chamber of Deputies." Political Science Quarterly, 21 (3): 475-497.

[52] Wallack, J. 2008. "India's Parliament as a Representative Institution." India Review, Vol 7, Issue 2.

[53] Williams, Brian D. and Indridason, Indridi H. 2014. "Luck of the Draw? Members Bills, the Electoral Connection \& Party List Placement", Working Paper.

[54] Wilson, Woodrow. 1911. The state: elements of historical and practical politics. D.C. Heath and Co: Boston.

[55] Wittreck, Fabien. 2007. "Parliamentary Law in Germany." In Constitutionalism and the Role of Parliaments, edited by Katja S Ziegler, Denis Baranger, Anthony W Bradley. Bloomsbury Publishing.

[56] Van Reybrouck, David. 2016. Against Elections: The Case for Democracy. Bodley Head Publishers. 